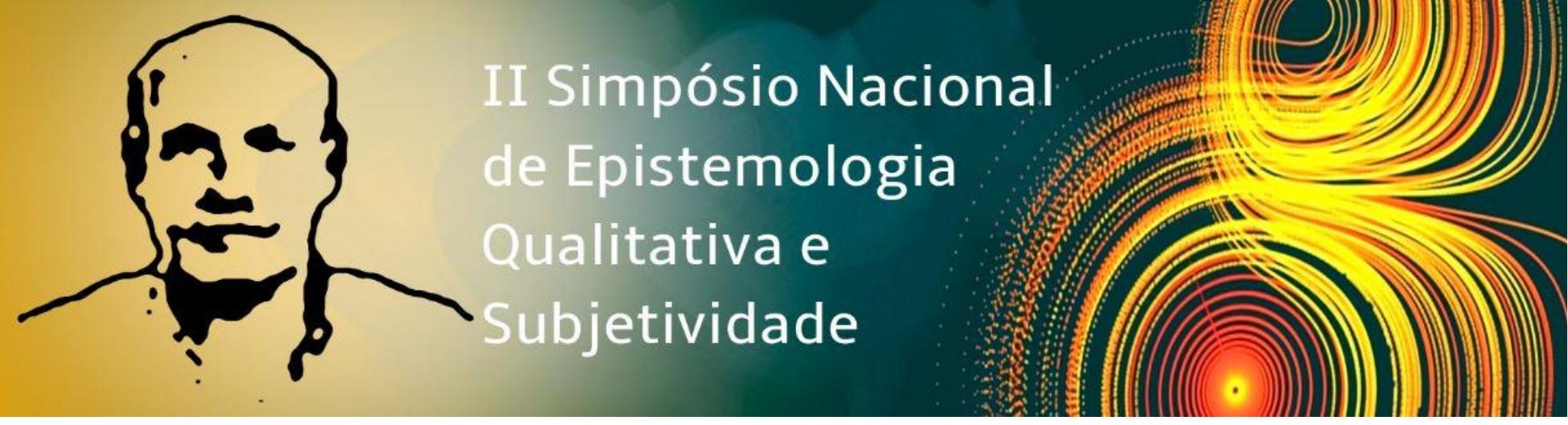

Eixo temático: A utilização da metodologia qualitativa e a metodologia construtivointerpretativa na pesquisa e na prática profissional

\title{
Produção de sentidos e polivitimização: uma proposta de pesquisa
}

Amanda Pinheiro Said, Universidade de Brasília, amandapsaid@gmail.com Liana Fortunato Costa, Universidade de Brasília, lianaf@terra.com.br

\section{Resumo}

Ao fenômeno em que uma mesma vítima sofre diversos tipos de violências, dá-se o nome polivitimização (FINKELHOR; ORMROD; TURNER; 2007). As pesquisas nesta área têm importante relevância social e acadêmica, embora sejam, especialmente no Brasil, incipientes. Sabe-se que as vítimas de abuso sexual do sexo masculino tendem a ser mais polivítimas do que as do sexo feminino (OLIVEIRA et al, 2014) e que a ocorrência de polivitimização agrava as consequências para as chamadas polivítimas (CULLATA et al, 2017). Tais dados, porém, amparam-se em uma maioria de estudos quantitativos, conduzidos em outros países, dificultando a compreensão ampla, complexa e contextual que o fenômeno requer. Por isso, ao considerar as especificidades que permeiam a polivitimização, este trabalho objetiva apresentar uma proposta de pesquisa em que se defende o uso da epistemologia qualitativa (GONZÁLEZ-REY, 2010) como método, forma de acesso e maior compreensão do tema junto aos atores envolvidos: vítimas, familiares e profissionais. A pesquisa se dará em um contexto de saúde pública do Distrito Federal e, para este processo, levar-se-á em conta a subjetividade e as experiências prévias e contextuais dos participantes na relação com a subjetividade e as experiências prévias e contextuais dos pesquisadores. Esse processo relacional é importante, pois as interpretações farão uso das relações como meio para a emersão e construção de novos sentidos acerca do tema aqui estudado. Defende-se que a pesquisa faça uso de encontros presenciais e conversacionais entre pesquisadores e participantes em que cada sujeito poderá necessitar e se favorecer de estímulos e recursos diversos para expressão da subjetividade (ex: desenhos, colagens, complemento de frases e 


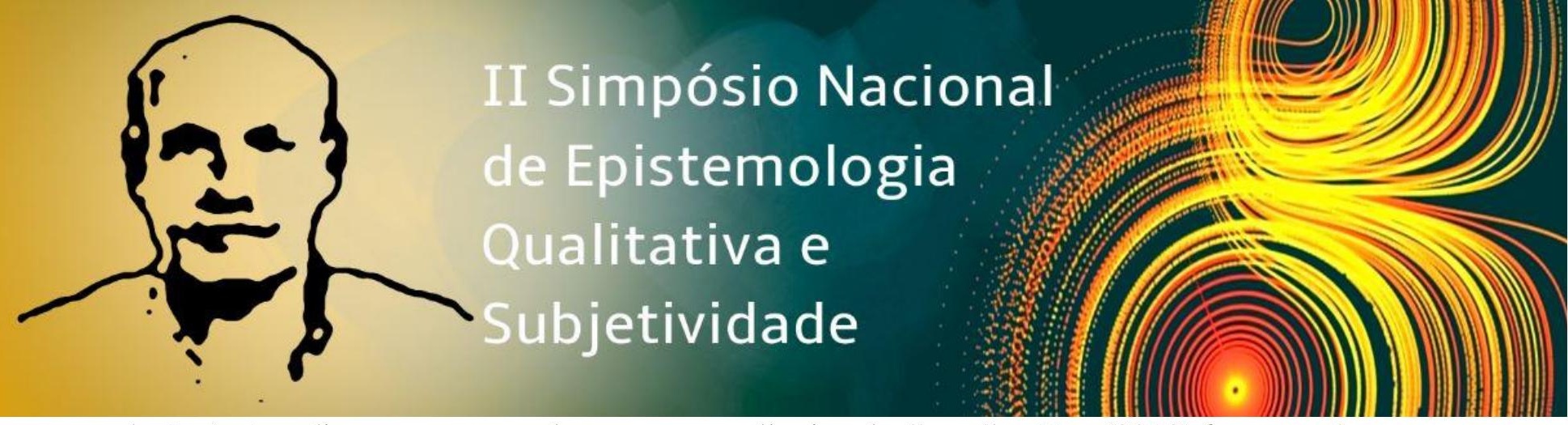

redações). Acredita-se que o uso da proposta qualitativa de González-Rey (2010) favorecerá a produção de sentidos acerca da polivitimização e que tais sentidos poderão favorecer a construção de conhecimento sobre o fenômeno a partir do olhar dos muitos atores envolvidos. A epistemologia qualitativa de González-Rey (2010) também considera os possíveis processos de irregularidades, singularidade, plurideterminação, diferenciação, historicidade e interatividade que permeiam o fenômeno polivitimização. Além disso, utilizar a epistemologia qualitativa em pesquisas como esta também significa considerar o viés qualitativo como uma via possível para a produção de teorias e conhecimento sobre assuntos e temáticas complexas, como a aqui apresentada, de uma forma coesa e científica. Ademais, tal proposta poderá contribuir para ampliação do conhecimento que se tem na área de forma, ao mesmo tempo, aprofundada e contextual, podendo, assim, embasar e favorecer o planejamento de ações e intervenções aos sujeitos que experenciam o fenômeno da polivitimização.

Palavras chave: Polivitimização, meninos vítimas de abuso sexual; produção de sentidos.

\section{Referências}

CULLATA, E et al. Sexual revictimization: a routine activity theory explanation. Journal of Interpersonal Violence, p. 1-25, 2017.

FINKELHOR, D.; ORMROD, R. K.; TURNER, H. A. Poly-victimization: a neglected component in child victimization. Child Abuse \& Neglect, v. 31, n. 1, p. 7-26, 2007.

GONZÁLEZ-REY, F. Pesquisa Qualitativa e Subjetividade: Os Processos de Construção da Informação. São Paulo: Cengage Learning, 2010.

OLIVEIRA, J. R et al. Violência sexual e coocorrências em crianças e adolescentes: estudo das incidências ao longo de uma década. Ciência \& Saúde Coletiva, v. 19, n. 3, p. 759-771, 2014. 